\title{
Focus on Tragic Fate of Lower-class Female Citizens in Social Transition Period
}

\author{
-A Case Study of Film Feng Shui \\ Hong Tang
}

Guangxi Economic and Trade Polytechnic, Nanning, 530021, China

Keywords: film adaptation, Feng Shui, fate tragedy, personality tragedy

\begin{abstract}
Film Feng Shui is adapted from the novel of the same name by Fang Fang with strong tragedy consciousness and realism style of the original novel. This film focuses on tragic fate and personality of heroine Li Baoli, and leads the audience to think about living dilemma of lower-class female citizens in social transition period.

Female writer Fang Fang, from Wuhan, is one of representative writers of Chinese "New Realism" School, and her novels focus particularly on fate of females from all classes and especially intellectuals and lower-class citizens. In a series of novels with females as the heroines such as Where Is Home, Running Flames, and Feng Shui etc, Fang Fang builds a world of females, reveals fate of females and implies profound critical discourse of females with words full of enthusiasm and painstaking efforts. In December 2012, her novel Feng Shui was adapted into a film of the same name and released to the public. This film is directed by Wang Jing with strong tragedy consciousness of the original novel, focuses on tragic fate and personality of the heroine, and leads the audience to think about living dilemma of lower-class female citizens in social transition period.
\end{abstract}

\section{Fate tragedy}

"Fate tragedy refers that social and historical inevitability or the force of nature is opposed to human as an incomprehensible and irresistible fate, resulting in a tragic end", i.e. "Human cannot get rid of fate". [1] Writing of Fang Fang worships fatalism. She has once said that: "Life is difficult for many people, while such difficulty is sometimes unrelated to ability, family property, luck, knowledge, environment, personality, money or body, but fate.” [2]

In novel Feng Shui, Fang Fang expresses clearly fatalism. The novel is named according to a saying in Feng Shui, and refers that if the door of house faces a window, roads turn round and round in front of the building like arrows shooting straightly at the building, so that Feng Shui is completely damaged while residents living in the building are doomed to be "unlucky". [3] Xie Fei, the film producer and art director, says that: "Fang Fang associates 'feng shui' of the house with the heroine and fate of her family story, which is a very important finding and unique artistic imagination. 'Fate' and 'fate confrontation' in Chinese sayings run through fate of the heroine.” [4] In the novel, Fang Fang conveys fatalism in words of Li Baoli's father. In Film Feng Shui, director Wang Jing applies such fatalism in Fang Fang's novel, and only combines and deletes characters, and expresses fatalism in words of Wan Xiaojing, a good friend of Baoli. Just like Oedipus the King in novel of Sophocles, a master of tragedy of ancient Greek, he couldn't get rid of his tragic fate of "killing his father and marrying his mother" at the end no matter how he struggles. The film adopts a grey-blue tone as a whole, which is consistent with overall tragic tone in the novel.

\section{Personality tragedy and social tragedy}

The film keeps the same with the original novel in terms of character portrayal. Director Wang Jing, who shoots documentary films at the beginning, shows a strong documentary style in the film with an objective narrative perspective and no subjective judgment, and raises thinking of the audience through words and actions of characters.

The 1990s in which context the story happened was an uncertainty period when traditional 
system changed into modern system and the new conflicted with the old. With the comprehensive establishment of market economy, traditional social ethics were impacted. Li Baoli, a lower-class citizen born in Wuhan, has quite distinctive characteristics of the times in social transition period: energetic, anxious to outdo others and possessive. She is kind but domineering with crude language, has certain feminine consciousness in marriage but merely takes marriage as a possession, has the spirit of self-sacrifice for the family but fails to think about how to maintain gender balance and get respect from family members. The inevitability of her tragic fate is doomed just because of her lack of a clear understanding and reflection of herself and life.

(I) Examine the pain of marriage. Marriage is an art that shall be operated jointly by both husband and wife with heart and wisdom on the basis of equality. However, Li Baoli takes marriage as a possession. At the beginning, her mate choice has utilitarian features of commodity economy era, and accepts Ma Xuewu's proposal because of his junior college degree; besides, she has been living in a sense of superiority when Ma Xuewu courts her. With such a psychology, Li Baoli behaves aggressively in family, steals the show everywhere, lacks tenderness and delicateness as a female, and shows no true love and respect for her husband. She has crude words and deeds at home, and a messy image; criticizes her husband in front of outsiders, which damages the dignity of Ma Xuewu extremely. Most tragically, she is not aware of her problem at all, and feels nothing about her husband's emotion changes.

Because of this, Li Baoli can't understand why Ma Xuewu asks for a divorce and has love affairs; and disapproves Xiaojing's friendly reminder "You leave Ma Xuewu no choice to this road (having love affairs)!" Even when making a phone call to inform against Ma Xuewu, she calls directly without inner battle or consideration of serious consequences, just thinking about "not making her man possessed by other females". Afterwards, she doesn't understand why Ma Xuewu commits suicide in a river and doesn't mention about her in suicide note, and hasn't introspection. "I can't understand why he asks for a divorce and jumps off river since we move to this new house, what on earth the reason is?" "A useless man doesn't worth my tears."

A series of "incomprehension" of Li Baoli is the root of her pain of marriage. Through actions and fate of characters in the film, the audience is led to think about cultural lack of females in marriage. Since the ancient times, patriarchal gender system specifies temperament and traits of males and females with a cultural presupposition. As written in Jing Shen: "With particularity of Yin and Yang, males and females shall have different deeds. Males shall be masculine, while females shall be tender; males shall be strong, while females shall be weak.” This clearly reflects a stereotype of female image in traditional Chinese patriarchal society. With continuous social progress and deepening of women's liberation movement, the society gives modern females a space for independent and flamboyant personality. Li Baoli's aggressiveness in marriage seemingly overturns traditional gender pattern of strong male and weak female, but doesn't mean women's liberation in the true sense and only moves from one kind of inequality towards another. According to gender view of Marxism, the sign of women's liberation is the equality between men and women. Feminism advocates maintaining a harmonious relationship between men and women with characteristics of both genders on the basis of equality. Tragedy of Li Baoli tells us that imbalance to either side would lead to tragedies. On the other hand, "Love must be constantly updated, developed and created", as discussed by Lu Xun a hundred years ago through tragedy of Zijun in Regret for the Past. However, in current society, a lot of females still take marriage as the end of struggle and think that they get married once for all. Li Baoli after marriage has been immersed in her superiority when Ma Xuewu tries hard in pursuit of her, but hasn't realized that her beauty has all gone over time while her personal charm hasn't been improved with time. The film image of $\mathrm{Li}$ Baoli shaped by the director is fully consistent with the novel: she doesn't care about her appearance even if she has a good looking, always wears outdated "upper garment for the middle-aged", and ties a knot of hair. This can be found in footnotes of the novel: "Ma Xuewu lying in bed glances at Li Baoli and asks 'can't you buy a nightgown?' ... It's so ugly wearing an old T-shirt of a man. Li Baoli smiles, and says that it's the clothing that is ugly instead of the person who wears it. Ma Xuewu says God knows.” [5] Here, it can be seen that there is a certain gap 
between Li Baoli and her husband's aesthetic expectation, but she is not alerted and thinks that husband and wife just mean physical bond and a possession. She fails to understand that the real lasting marriage is based on mutual appreciation and understanding. A series of "incomprehension" of her finally leads to failure in marriage.

(II) Examine the pain of kinship. The second half of film mainly focuses on conflicts between $\mathrm{Li}$ Baoli and her son Ma Xiaobao, and arouses thinking of the audience on Li Baoli's "pain of kinship" by gradually intensifying conflicts. After suicide of Ma Xuewu, Li Baoli shows awe-inspiring braveness. "I will support the family alone." She gives up a relatively comfortable but low-income job of selling socks, and chooses "shoulder pole" which is high-income, laborious and lower-class. With a pair of thin shoulders, she starts work early and knocks off late over years no matter it is windy or rainy, and insists without regret. She gives all money that she earns to her mother-in-law, but eats the simplest street fast food. She just wants to earn as much money as possible to support her son's education, and would rather suffer for her son. However, when Li Baoli finally sees that her son is admitted to his ideal university after going through many hardships, she thinks that happiness finally comes after suffering, but only gets her son's resolution of taking her out of the house, which is undoubtedly the most fatal "arrows" piercing her!

Li Baoli is exactly a typical example of lower-class female citizens who live a hard, rough and confused life, have traditional virtues as Chinese women, and are diligent, kind, ready to help others (help for Mrs. He) and strongly responsible for families. Even if Li Baoli seems to be shrewd and fierce towards others, she tries her best and works hardly for her family, but still fails to change her marginalized status in family. Although certain changes have occurred in modern people's view on family and marriage during social transition period of China, deep psychological structure of patriarchal culture formed over thousands of years still exists, and the film arouses thinking of the audience by a series of plots from Ma Xiaobao's accumulated rancor to hostility to his mother. If Ma Xiaobao has finally a reason for hating his mother after knowing that his father dies because of his mother's report, his accumulated rancor to his mother in previous plots mainly comes from his mother's aggressiveness in family, and such aggressiveness overturns his ideal image pattern of "severe father and kind mother". In childhood, he is very dissatisfied with his mother's arrogant and domineering words and deeds towards his father. So, when his father commits suicide, he thinks that his father has depreciated respect as a man and loses the courage to live completely because his mother goes beyond gender hierarchy specified in the patriarchal society, and thus punches and kicks his mother saying: "Bring my father back!" As a result, no matter how Li Baoli works for this family afterwards, she can’t reduce Ma Xiaobao's resentment of her, as his resentment has completely outweighed his recognition of his mother's efforts. Repeated lenses of him putting up his father's portrait in the film are very good evidence, showing that he demonstrates constantly the existence of patriarchy and authority of husband to his mother by this way. At the end, he knows the truth of his father's suicide, and shows also deep patriarchal psychological structure in his heart: he forgives his father's love affairs, but feels "sick" about his mother's relationship with man after being widowed for a long time, and finally requires his mother to merely put his name on the property ownership certificate in order to expulse his mother. Ma Xiaobao exercises the authority of husband on behalf of his father Ma Xuewu, which can better prove the power of patriarchy than the former as a matter of fact. For Ma Baoli herself, lack of education and due thinking on life is also one of reasons for her "pain of kinship”. In fact, Ma Xiaobao’s resistance to her has been visible, but she is not alerted to communicate timely with her son and solve as early as possible. Except asking about his learning occasionally, Li Baoli hasn't any communication with him, and thinks that she has fulfilled her responsibilities and obligations as a mother by being fully devoted to making money to support the family and could gain respect and return from her son.

Based on the above analysis, Li Baoli keeps only a "living" state no matter for marriage or family and even the entire life, and her dull state of life is quite representative among lower-class female citizens. Females living in the transition period from the old to new society like Li Baoli begin to be aware of human instinct and have certain self-expression desire, but lack consciousness ability of life, self-recognition and thinking and still keep a crude and exhausted state of life. 
Director Wang Jing keeps the same realism technique of original novel, and arouses thinking of the audience on living dilemma of lower-class female citizens in social transition period through calm narration.

Even film Feng Shui hasn’t ideal box office sales, box office sales is not the main standard to evaluate its success in current immature Chinese film market as a literary film. This film wins high praise in film review circle with profound realism spirit and depth of reflecting social reality, which are exactly what the author would like to affirm.

\section{Acknowledgments}

This paper is funded by "Outstanding Middle-aged and Young Backbone Teachers Training Project for Institutions of Higher Education in Guangxi Province” (GJR [2013] No. 16).

\section{References}

[1] Yang Xin, Gan Lin. Principles of Aesthetics [M]. Peking University Press, 1993, P 280 281.

[2] Fang Fang. Spring for Tan Hualin [M]. Beijing: China Writers Publishing House. 2007.7, P 279.

[3] Feng Shui. Mtime. November 14, 2012.

[4] Money Is Not Sole or A Reason for the Existence of A Film. Dfdaily.http://www.dfdaily.com/html/150/2012/12/18/912863.shtml, December 8, 2012.

[5] Fang Fang. Feng Shui [M]. Chongqing: Publishing House, 2013.6, P 2. 